\title{
Online Social Media and Political Awareness in Authoritarian Regimes
}

\author{
ORA JOHN REUTER AND DAVID SZAKONYI*
}

Do online social media undermine authoritarianism? The conditions under which online social networks can increase public awareness of electoral fraud in non-democracies are examined in this article and it is argued that a given online social network will only increase political awareness if it is first politicized by elites. Survey data from the 2011 Russian parliamentary elections show that usage of Twitter and Facebook, which were politicized by opposition elites, significantly increased respondents' perceptions of electoral fraud, while usage of Russia's domestic social networking platforms, VKontakte and Odnoklassniki, which were not politicized by opposition activists, had no effect on perceptions of fraud. This study elucidates the causes of post-election protest by uncovering a mechanism through which knowledge of electoral fraud spreads.

Authoritarian regimes restrict media freedom so that citizens cannot gain access to information that might turn them against the regime. But the rise of new media, such as the internet and online social networks, has led many observers to question whether authoritarian regimes can still control the flow of information within their borders. ${ }^{1}$ According to these observers, new media lower the costs of acquiring independent information, reduce barriers to collective action, and, thereby, undermine authoritarianism.

At the same time there are pessimists who argue that new media may not destabilize authoritarianism, as authoritarian leaders adopt new methods for controlling dissent in these arenas. ${ }^{2}$ Indeed, some scholars have questioned whether the real effect of new media during the Arab Spring was as pronounced as journalistic accounts suggested, ${ }^{3}$ while recent studies (in democracies) find that the effect of new media usage on political awareness is mixed. ${ }^{4}$

This disharmony in the literature is due to the tendency of political scientists to treat new media as a 'black box'. ${ }^{5}$ In other words, little effort is made in the existing literature to spell out the causal mechanisms by which this or that type of online activity translates into specific outcomes that undermine authoritarianism. In this article, we focus on how a specific type of online activity contributes to a specific outcome thought to be correlated with authoritarian breakdown. Concretely, we study how the usage of online social

* Department of Political Science, University of Wisconsin, Milwaukee; Department of Political Science, Columbia University (email: ojreuter@gmail.com). This article is an output of a research project implemented as part of the Basic Research Program at the National Research University Higher School of Economics (HSE). Additional research support was provided by the National Council for Eurasian and East European Research and the Social Science Research Council Eurasia Program. Replication files and supplementary appendices for this article can be found on the author's website: https://sites. google.com/site/ojreuter/

${ }_{1}$ Cottle 2011; Shirky 2011.

${ }^{2}$ Morozov 2011.

${ }^{3}$ Lynch 2011.

${ }^{4}$ Groshek and Dimitrova 2011; Kaufhold, Valenzuela and Gil de Zúñiga 2010.

${ }^{5}$ Farrell 2012. 
media - internet-based social networking sites such as Facebook and Twitter - affects political awareness in authoritarian regimes. We argue that online social media usage can, under certain conditions, increase political awareness in authoritarian regimes. In authoritarian regimes, opposition elites spread political information on certain networks, but not on others. Thus, we argue that usage of a given online social network will only increase political awareness if the network itself has been politicized.

To evaluate these claims, we examine variation in public awareness of electoral fraud in an electoral authoritarian regime. Public awareness of fraud is uniquely important in electoral authoritarian regimes because of its potential to ignite anti-regime mobilization. ${ }^{6}$ There are a large number of cases in which widespread electoral fraud has sparked anti-regime protests (for example Georgia 2003, Ukraine 2004, Iran 2009, Russia 2011). How is it, though, given the difficulty of acquiring information about electoral fraud in state-controlled media environments, that citizens learn of these violations? By elucidating how such information is spread in the twenty-first century, this article sheds light on the causes of electoral revolution under autocracy.

We test our claims with data from a nationally representative survey of 1,600 adults conducted in the wake of the 2011 Russian parliamentary election. In these elections, independent observers identified large-scale electoral fraud, but, as our data shows, there was significant variation in public awareness of this fraud. Controlling for a range of factors that might predict awareness of fraud, we find that usage of Facebook and Twitter, which were primed by opposition activists with information about fraud, significantly increased the probability that an individual perceived significant electoral violations. Meanwhile, opposition activists did less to politicize more widely used native Russian platforms, such as VKontakte and Odnoklassniki, and usage of those platforms had no effect on a respondent's probability of perceiving electoral violations.

We also find that the effect of Facebook/Twitter usage on awareness of fraud is larger in regions with relatively high levels of press freedom. The ability of activists to politicize social networks depends on the availability of 'inputs', or information that can be fed into online social networks. In regions with relatively high levels of press freedom, more such information was available in the media, which could then be used to prime social networks. Finally, we find that the effect of Facebook/Twitter usage on awareness of fraud is stronger among erstwhile supporters of the regime.

This work contributes to the growing literature on the Internet and politics. ${ }^{7} \mathrm{We}$ identify a specific mechanism by which usage of specific types of new media can undermine authoritarianism. We also add nuance to the growing journalistic consensus that online social networks are an unambiguous force for democratic change by showing that not all social networks have an effect on levels of political awareness.

Thus, while our study suggests that online social media have the potential to undermine authoritarianism, a note of caution is also warranted. Fewer than 7 percent of Russians use Facebook or Twitter - the networks that actually have an effect on political awareness - so the total effect of these networks on public attitudes remains limited. Although usage of Western social networks is increasing in Russia, current rates of usage are still low (as they are in many non-democracies), so observers should not overestimate the ability of Facebook and Twitter to undermine authoritarian regimes in the near future. Meanwhile,

6 Tucker 2007.

7 Farrell 2012. 
almost one in three Russians use domestic social networking platforms, which, as we show, are more easily monitored and controlled by the government. This potential for government intervention dissuades opposition elites from spreading anti-regime information over those networks. Thus, authoritarian governments are not defenseless in the face of technological change.

Finally, we have put forth a new approach to the question of how citizens in nondemocratic regimes acquire information and develop actionable anti-regime grievances. Protest movements develop from common perceptions of regime malfeasance, but achieving generalized public awareness of such malfeasance is difficult. ${ }^{8}$ We highlight a mechanism by which the informational cascades that sometimes bring down modern authoritarian regimes can get their start.

\section{POLITICAL AWARENESS, NEW MEDIA, AND AUTHORITARIAN REGIME SURVIVAL}

Scholars have devoted considerable attention to the question of how citizens learn about political events from the media. ${ }^{9}$ Most scholarship has focused on the effect of traditional media (e.g. television, radio, and newspapers), but recent years have witnessed a rapid expansion in the number of studies examining the effect of internet usage on political awareness. ${ }^{10}$ Scholarship on the political effects of online social media - i.e. online social networking - is relatively scarce, however. ${ }^{11}$ Some recent studies suggest that participation in online social groups increases levels of political engagement, ${ }^{12}$ while other recent works find no relationship. ${ }^{13}$

In authoritarian regimes, where access to independent traditional media is limited, some scholars have argued that internet usage can expose users to alternative sources of information and make it harder for governments to control the political information that citizens consume. In 2011, Western media was filled with accounts of how Facebook and Twitter facilitated anti-regime mobilization during the Arab Spring. ${ }^{14}$ Using an instrument for internet penetration in Malaysia, Miner finds that internet usage increased exposure to alternative viewpoints, which turned popular opinion against the incumbent regime and contributed to a decline in ruling party vote shares. ${ }^{15}$ Experimental evidence from Tanzania also suggests that giving citizens access to the internet later influenced their evaluation of electoral fairness. ${ }^{16}$

At the same time, important recent work has questioned whether new media really undermines authoritarian regimes. Scholars have highlighted the many ways that authoritarian leaders can harness the internet - including social media - to spread disinformation, monitor opponents, and gather information. ${ }^{17}$ In this vein, some analyses

8 Kuran 1991; Tucker 2007.

9 De Vreese and Boomgaarden 2006; Eveland and Scheufele 2000; Zaller 1992.

10 Most scholarship finds that the internet increases political awareness (e.g. Boulianne 2009; Farrell 2012; Gil de Zúñiga, Puig-I-Abril and Rojas 2009), but see Sunstein (2002) for a dissenting view.

11 Following Boyd and Ellison (2007), we define online social network sites as 'web-based services that allow individuals to (1) construct a public or semi-public profile within a bounded system, (2) articulate a list of other users with whom they share a connection, and (3) view and traverse their list of connections and those made by others within the system'.

12 Pasek, More and Romer 2009; Swigger 2012.

13 Groshek and Dimitrova 2011; Kaufhold, Valenzuela and Gil de Zúñiga 2010.

14 Cottle 2011; Howard and Hussain 2011; Lynch 2011; Tufekci and Wilson 2012.

15 Miner 2011.

16 Bailard 2012.

17 Aday et al. 2010; Deibert and Rohozinski 2010; Kalathil and Boas 2003; Morozov 2011. 
have urged caution in drawing a link between protest participation and social media usage in Egypt. ${ }^{18}$

How do we reconcile these seemingly contradictory perspectives about the effect of internet usage on political change in non-democratic regimes? As we argue below, much depends on the type of platform being accessed by users and the extent to which those platforms are politicized by anti-regime activists.

\section{AWARENESS OF ELECTORAL FRAUD UNDER AUTHORITARIANISM}

In this article, we focus on how online social media usage affects a specific type of political awareness: knowledge of electoral fraud. Recent scholarship has argued that widespread knowledge of electoral fraud can spur mass mobilization against the regime. ${ }^{19}$ Indeed, recent history contains many examples - such as the Orange Revolution in Ukraine, the Rose Revolution in Georgia, and the Bulldozer Revolution in Serbia - of fraudulent elections inciting massive anti-regime mobilization followed by regime change.

Thus, for those interested in understanding how and when electoral authoritarian regimes make the transition to democracy, there are few arenas of civic engagement that are more important than public awareness of electoral fraud. But awareness is not automatic. By its very nature electoral fraud is covert, and authoritarian regimes take special measures - for example, media censorship, repressing civil society, and intimidation - to ensure that information about fraud does not reach the public. ${ }^{20}$ The spread of information about electoral fraud requires first that someone - election observers, journalists, or ordinary citizens - take note of abuses. And second, it requires that first-hand accounts are passed on to others, for example by civil society groups (such as vote monitoring organizations) or journalists. These second-hand accounts of electoral fraud may then spread via traditional media or horizontally via new media, such as social networking sites. Similarly, first-hand witnesses of fraud may share their experiences through word of mouth or new media.

Despite all these hurdles, the mass public sometimes becomes aware of electoral fraud in electoral authoritarian regimes, unleashing a process that can lead to large-scale antiregime mobilization. And yet in other cases, publics remain ignorant of rampant electoral fraud. Moreover, as we demonstrate for the case of Russia below, there is significant variation in awareness of electoral fraud across citizens within any given country. What explains this variation? Given all the control that authoritarian regimes exercise over channels of communication, the strong incentives that autocrats have to hide fraud, and

18 Lynch 2011.

19 Beissinger 2007; Thompson and Kuntz 2004; Tucker 2007.

20 Since authoritarians try so hard to hide electoral fraud, social media might have an even larger effect on awareness of less sensitive political issues. In this sense, electoral fraud would be a 'crucial case'. However, we might observe a substitution effect in which social media usage has a larger effect on awareness of those issues that traditional media sources cannot cover. In that case, electoral fraud could be a crucial case of a different variety, and social media might have an even larger impact on awareness of issues that are even more sensitive than electoral fraud, such as human rights violations. It is beyond the scope of this article to theorize specifically about the effects of social media on all types of political awareness, so we are reluctant to call electoral fraud a 'crucial case' of either variety. One reason that we are reluctant to venture theories about other political issues is that the effect of social media on awareness depends on the average user's personal experience with an issue. Once a network was primed, information on electoral fraud spread quickly in Russian social media because individual users chimed in with their own experiences. It is hard to see how such informational snowballs could accumulate around an issue, such as torture, with which few users have direct experience. 
the high costs associated with acquiring information about electoral fraud, how is it that citizens become informed about electoral fraud in authoritarian regimes?

\section{ELECTORAL FRAUD AND THE 2011 PARLIAMENTARY ELECTIONS IN RUSSIA}

On December 4, 2011, Russia held its sixth parliamentary election since the break-up of the Soviet Union. The election took place under the framework of Russia's electoral authoritarian regime, in which the ruling party, United Russia, controls the vast majority of elected offices at the national, regional, and local level. Although United Russia's popularity had waned slightly over the course of 2011, most observers expected the party to win the elections easily and secure a comfortable majority. ${ }^{21}$

The results of the elections were a mild shock to most. United Russia managed to garner only 49.32 percent of the vote, which translated into only a slim thirteen-seat majority in the Duma. Moreover, as became clear in the immediate aftermath of the election, the authorities had perpetrated fraud in order to secure that result. In addition to manipulations of the electoral process that occurred well before election day, such as repression of the opposition and media censorship, ballot-box fraud was widespread on election day. Opposition leaders estimated that ballot box fraud accounted for as much as 20 percent of United Russia's vote total. More objective sources estimate slightly lower, but still significant, levels of fraud. In one field experiment conducted by a team of Russian social scientists election observers were randomly assigned to polling stations in Moscow and United Russia received, on average, 11 percent fewer votes in polling stations with observers. ${ }^{22}$

Allegations of electoral abuse touched off mass protests, the largest of which numbered almost 100,000 protesters. Still, awareness of electoral violations varied widely. According to a representative survey of 1,600 Russians conducted by the Levada Center in December 16-20, 2011, 55 percent of Russians thought there were either no violations or insignificant violations in the elections, while 19 percent thought that there were indeed electoral violations significant enough to affect the final results of the elections. Below, we identify the conditions under which usage of social networks influenced voters' assessments of the severity of electoral fraud.

\section{ONLINE SOCIAL MEDIA AND AWARENESS OF ELECTORAL FRAUD}

Online social media can be an especially powerful tool for spreading information about electoral fraud. In contrast to regular internet browsing, which requires an intentional page click to access information, online social media often inadvertently presents users with disparate information streams. Depending on the architecture of the online network, members may scroll quasi-randomly through recommended links to outside outlets as well as through friends' commentaries and discussions. By aggregating submissions from an enlarged network, users are more prone to 'accidental exposure' to a wider variety of sources and viewpoints about the conduct of elections. Increased variety of news sources has been shown to be correlated with improved knowledge and objectivity in evaluating political events. ${ }^{23}$ Thus, online social media users need not actively seek information on fraud in order to be exposed to it. This mitigates the extent to which audience segmentation might diminish social media's effect on awareness of electoral fraud.

21 Reuter 2011.

22 Enikolopov et al. 2013.

23 Mullainathan and Shleifer 2005; Prior 2005. 
Online social media are also distinguished by their ability to provide information that is deemed trustworthy. Just as citizens make inferences on the credibility of traditional news sources, ${ }^{24}$ online users evaluate the trustworthiness of information. Online social media are noteworthy because links and news items can be shared among socially networked 'friends'. News items passed along by these trusted acquaintances may carry additional weight in influencing the way information is processed. ${ }^{25}$ Thus, information on fraud that is recommended ('liked') by trusted friends, family, or associates is more likely to be assimilated.

Finally, social networks open up opportunities for users to engage in informal communication based on informational inputs. Discussions emerge organically on most major networking sites through comments on shared links and articles. Interactions within personal relationships have been found to strongly influence political views and improve opinion formation. ${ }^{26}$ Online communities can act as an extension of the physical discussion networks found to be so powerful, ${ }^{27}$ while at the same time introducing and incorporating various forms of media into the dialogue. Indeed, online group participation appears to have reinforcing effects on political sophistication by broadening and deepening political thinking. ${ }^{28}$ Thus, the social component of these online sites creates a 'collaborative ecosystem' where user-submitted information can spread quickly and compete with official news narratives about fraud. ${ }^{29}$

However, as scholars of offline social networks have cautioned, analysis of online social media usage must begin with an understanding of the content and structure of networks. ${ }^{30}$ Many of online social media's theoretical advantages uniquely depend on the active participation of influential elites to drive information distribution across networks. These elites help produce informational contagion, given their large number of followers and active presence on networks. ${ }^{31}$ Once information is introduced into the network it tends to spread organically, but this process of diffusion is facilitated if elite users initiate the process. In the case of electoral fraud awareness, the ability of online social media to help disseminate independent information depends critically on influential individuals who can highlight, frame, and promote specific evidence that contradicts the official state line.

Under this stylistic model, it seems natural that online social media outlets can vary widely according to the presence or absence of critical elites that prime the network space. For our example of electoral fraud, we argue that a given social media outlet will only

${ }^{24}$ Miller and Krosnik 2000.

${ }^{25}$ Bakshy et al. 2012.

${ }^{26}$ Huckfeldt and Sprague 1995.

${ }^{27}$ Campus, Pasquino and Vaccari 2008.

${ }^{28}$ Gajora 2011.

29 Alexanyan et al. 2012.

${ }^{30}$ Lessig 1999.

31 Siegel 2008; Tonkin, Pfeiffer and Tourte 2012; Yang and Leskovec 2010. The structure of the network itself may determine how essential elites are to information dissemination. Siegel (2008) outlines four types of network structures: Small World, Village, Opinion Leader, and Hierarchical. Though we know of no work that applies this typology to online behavior, Siegel's definition of an Opinion Leader as a place where 'most people have few connections, while a few - the opinion leaders - have many' ('star' or 'wheel' networks), appears closest to our understanding of how elites influence information dispersion on online social media (Siegel 2008). His prediction about information diffusion for Opinion Leader networks argues that the number of elites present is most important for behavior adoption and diffusion, as followers tend to follow leaders. 
increase popular awareness when it is politicized by core opposition activists that are actively working to share more independent information about political events. In other words, the effect of online social media usage on awareness of electoral fraud is dependent on the type of political information that has been injected into the network. Among social networks without this elite politicization, information inputs about electoral fraud would neither make their way into the network structure nor find popular footing; users would simply not be exposed to the variety of political information necessary to build awareness. Thus, we argue that social networks containing information about electoral violations will increase awareness of fraud in non-democratic regimes, while those that have not been politicized with such information will not raise awareness.

This perspective also generates predictions about how the surrounding information environment will affect the way that online social media can be used to spread awareness about electoral fraud. Conventional wisdom holds that the internet and online social media are more important conduits of information dissemination in authoritarian regimes precisely because other conduits of information dissemination - free traditional media - are largely absent. This is plausible for the internet as a whole, but the discussion above suggests that online social media must first be primed with information about fraud if it is to significantly amplify users' awareness of fraud. Thus, our framework suggests that the effect of online social media usage on awareness of electoral fraud in authoritarian regimes like Russia will actually be higher in environments with relatively free traditional media. In such environments, opposition activists and elite users can more easily gain access to secondary information about vote fraud, which can be used to prime online social media.

\section{ONLINE SOCIAL MEDIA AND THE 2011 RUSSIAN PARLIAMENTARY ELECTIONS}

In the aftermath of the December 2011 parliamentary elections, most available information on electoral fraud was generated by and spread through online media. State-run television was mostly silent on reports of fraud. Private television networks, meanwhile, devoted some attention to fraud, but the vast majority of Russians - 72 percent according to a December 2011 poll - count state-run television as their primary news source. ${ }^{32}$ Coverage of electoral fraud was varied in print media, with state-run newspapers avoiding the issue, while a handful of private newspapers run by the Moscow intelligentsia - for example Novaya Gazeta, Kommersant, Vedomosti, and Nezavisimaya Gazeta-devoted significant page space to electoral abuses. However, these newspapers have only limited daily circulations and none reach outside major urban areas.

By contrast, prominent internet news outlets such as Slon.ru, Gazeta.ru, and the New Times wrote about reports of electoral fraud and printed analyses by social scientists. Blogs - particularly those hosted by LiveJournal.com - buzzed with posts detailing firsthand accounts of fraud, analyses of electoral returns, and links to articles on electoral fraud. ${ }^{33}$ Of the top twenty-five Russian LiveJournal blogs, eight were run by opposition activists who posted extensively about electoral fraud during the 2011 elections. $^{34}$

${ }^{32}$ Levada Courier Survey, Levada Center, December 2011.

${ }^{33}$ Unfortunately, hard data on the content of blog posts and social network messages is not available, so it is difficult to determine with certainty the relative share of content devoted to the elections. These statements, as well as those below, reflect the sentiments of media coverage at the time. However, as the discussion of Figure 1 notes, it does seem that the elections increased usage of social networking platforms.

${ }^{34}$ http://blogs.yandex.ru/top/lj/, accessed July 15, 2012. 


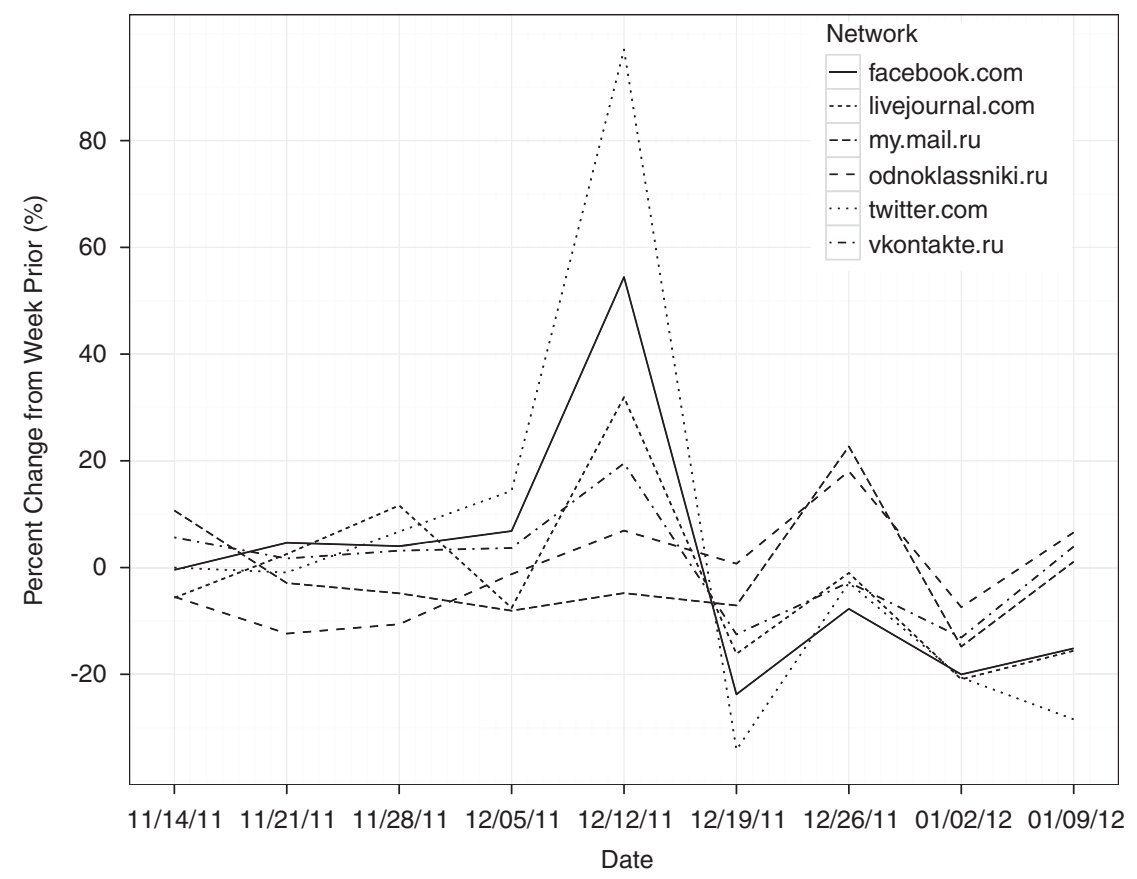

Fig. 1. Spikes in social network activity in Russia

Russia's most well-known political blogger, Alexei Navalny, ran Russia's third most popular LiveJournal blog, which prior to the election was used primarily as a platform for publicizing corruption scandals. During the election campaign, however, Navalny focused more attention on electoral abuses, and in December 2011, Navalny became one of the leading members of the committee responsible for organizing street protests.

Other online media also buzzed with information about electoral fraud. Before and after the elections, eyewitnesses posted accounts of their experiences with fraud on these sites, and opposition activists passed on secondary information about electoral abuse. Figure 1 shows the week-on-week percentage change in usage for several popular online social media platforms in Russia. As the figure shows, Russian social network usage experienced a dramatic spike during the week of the December 4 elections. As discussed below, Facebook and Twitter traffic increased particularly sharply.

We have argued that usage of online social networks will only increase a citizen's awareness of government malfeasance, such as electoral fraud, if that network has been politicized to contain information on malfeasance. In the case of Russian electoral fraud, activists chose to concentrate their politicization efforts more heavily in Western social media outlets such as Facebook, Twitter, and LiveJournal, while native Russian social networks such as VKontakte, Odnoklassniki, MoiKrug, and MoiMir remained less politicized. In the remainder of this section, we describe these networks and how they were used at the time of the 2011 Russian State Duma elections. Then, on the basis of the argument above, we derive hypotheses about how usage of social networks in Russia affects awareness of electoral fraud. 
TA BLE 1 'Do You Regularly Spend Time on Social Networking Sites? If so, Which?'

\begin{tabular}{lcc}
\hline \hline Network & Share of internet users $(\%)$ & Share of all respondents $(\%)$ \\
\hline Odnoklassniki & 51 & 25.3 \\
VKontakte & 47 & 23.4 \\
Moi Mir & 22 & 10.8 \\
Facebook & 10.4 & 5.2 \\
Moi Krug & 6.7 & 3.3 \\
Live Journal & 3.8 & 1.9 \\
Twitter & 3.3 & 1.6 \\
\hline \hline
\end{tabular}

Although Facebook is the most-used social networking site in 127 countries, VKontakte is the largest social networking site in Russia. ${ }^{35}$ Founded in 2006, VKontake is jointly owned by a group of Russian entrepreneurs and the Mail.ru group, 45 percent of which is owned by metals magnate and Gazprom executive Alisher Usmanov. With a design interface that bears a striking resemblance to Facebook's, VKontakte targets a general audience and offers features - private/public messaging, groups, privage/public pages, and image tagging that are nearly identical to those offered by Facebook. As Table 1 shows, 47 percent of Russian internet users - 23 percent of the population - reported using VKontakte as of December $2011 .^{36}$ Only 10.4 per cent of internet users used Facebook. ${ }^{37}$

Russia's other major social networking site, Odnoklassniki (Classmates), was founded in 2006 by Russian programmer Albert Popkov. Since August 2010, the site has also been owned by the aforementioned Mail.ru group. Odnoklassniki has all the typical social networking features. Two other native Russian social networks are Moi Mir and Moi Krug, each of which is significantly smaller than OdnoKlassniki or VKontakte.

Live Journal is a blogging platform with many social media features, such as detailed member profiles, 'friending', private messaging, and an active commenting culture. LiveJournal was founded as a Western blogging platform, but, after becoming the most popular blogging platform in Russia, it was sold to SUP media, an international media company based in Moscow. Over half of the site's visitors are situated in Russia. ${ }^{38}$

In Russia, Facebook, Twitter, and LiveJournal were most likely to be primed with information on electoral fraud, while considerably less information on electoral fraud circulated on native Russian social networking sites. Looking again at Figure 1, we see that the spikes in usage of Facebook, Twitter, and, to a lesser degree, Live Journal during

\footnotetext{
35 According to data compiled in June 2012 by the social media analyst Vincenzo Cosenza http:// vincos.it/world-map-of-social-networks/

36 Levada Courier Survey, Levada Center, December 2011 (see fn. 21 for survey methodology). Data based on both registered users and page views shows that VKontakte is larger than Odnoklassniki. For example, according to data from the Russian affiliate of the market research firm. TNS Global, VKontakte was used by 53.4 percent of Russian Internet users in August 2011, while Odnoklassniki was used by 38 percent of users. MoiMir was used by 43.8 percent of users and Facebook was used by 24 percent. Our survey data, which is based on a question about 'regular' communicationon social networking sites tells a slightly different story, but all data sources agree that VKontakte, MoiMir, and Odnoklassniki are much more widely used than either Facebook or Twitter.

${ }^{37}$ Notably, unlike some contemporary authoritarian regimes like China and Iran, Russia does not block access to Western social networking sites, so the dominance of domestic social media platforms is due to market factors.
}

38 Alexa Web Information. http://www.alexa.com/siteinfo/livejournal.com, accessed July 22, 2012. 
the week of the elections were much more pronounced than spikes in the usage of native Russian social networking platforms. This indicates that political information about the elections was circulating primarily on Western outlets.

Indeed, press reports paint a picture of activists using Facebook and Twitter for sharing political information while shunning VKontakte. ${ }^{39}$ The first mass protest after the elections (on December 10th) was organized by political activists via Facebook. Two days before the protest, 30,000 people had signed up to attend on the event's Facebook page, while only 10,000 were signed up on VKontakte (the event had no page on OdnoKlassniki). Considering the fact that VKontakte has five times as many users as Facebook, this disparity is even more noteworthy.

Prominent elite opposition activists focused their social media efforts on Western outlets. Alexei Navalny, Russia's most popular political blogger, maintained an active public Facebook page, with 23,466 'Likes' and multiple posts each day. ${ }^{40} \mathrm{He}$ is also an active Twitter user with over 250,000 followers. On the day of the elections, Navalny tweeted over 250 times related to the election. ${ }^{41}$ His VKontakte page, meanwhile, contains few updates and has a mere sixty followers. ${ }^{42}$ He has no page on OdnoKlassniki or Moi Mir.

While quantitative data on how information is disseminated via Facebook is not available, data on Twitter has been analyzed. As studies have found, political discourse on Russian Twitter is dominated by elite nodes that disseminate links. ${ }^{43}$ From March 2010 to March 2011, tweets by Navalny, Oleg Kashin, Marina Litvinovich, and Anton Nossik were among the most popular opposition Twitter users. ${ }^{44}$

It is not immediately evident why elite activists prefer Western social media platforms over domestic ones. After all, domestic platforms contain many more users, and, hence, a larger potential audience. Some suggest that activists prefer Western outlets for purely idiosyncratic reasons. As Russian journalist Grigorii Asmolov has noted, '[The use of Facebook for organizing mass protests] probably is explained by the fact that the people who kick started it all - that is journalists, bloggers, and political activists in Moscow - themselves actively use [Facebook] and slightly shun VKontakte for perhaps aesthetic reasons'.

Another reason that opposition activists may have eschewed domestic social media platforms has to do with ownership structure. In recent years, the Russian authorities have taken steps to limit Internet freedom through regulation and intimidation. Given this, it is perhaps not surprising that opposition activity on social media sites attracted the attention of Russian authorities during the 2011-12 election cycle. But Russian authorities found it much easier to apply pressure to domestically owned new media. Over the course of 2011, Live Journal was brought down no less than five times by denial of service attacks. In December 2011, the site suffered a ten-day barrage of attacks that took the site offline for much of election day, and sporadically thereafter. On December 9, four days after the elections, VKontakte's owner, Pavel Durov, was summoned by the

39 See, for example, Balmforth 2012.

${ }^{40}$ All statistics are as of July 22, 2012.

${ }^{41}$ See Figure 1 in the appendix.

42 Since the elections Navalny has chosen to concentrate more attention on building his VKontakte presence.

${ }^{43}$ Greene 2012.

${ }^{44}$ Greene 2012. 
Russian Federal Security Service (FSB) for questioning. On his Twitter feed, Durov displayed a copy of the summons and explained that FSB had requested that VKontakte close several anti-regime user groups on the site. ${ }^{45}$

Thus, opposition activists (and everyday users) had good reason to believe that their private communications could be compromised and their posts blocked if they utilized domestic social media outlets. A report by the Interfax news agency summed up the distinction between Western and domestic new media this way:

First, the websites of many major informational resources went down. Then, after the bulwark of Russian democratic thought, Live Journal, was hacked, jokes started to circulate in Facebook about when the hackers would bring down that final stronghold of free speech. But the stronghold held out and successfully aggregated hundreds of Twitter messages, YouTube videos, and links about the elections. Photos poured in. Commentaries were written. Users with thousands of followers posted information in their accounts about violations. ${ }^{46}$

Whatever the reason, these anecdotes suggest that Russian opposition activists may have put more effort into disseminating information about electoral fraud on Facebook and Twitter than they did on domestic platforms. Thus, following on our argument that users of politicized social networks will be more likely to demonstrate awareness of electoral fraud, our first two hypotheses are the following:

HYPOTHESIS 1: Usage of Facebook and Twitter will have a positive effect on awareness of electoral fraud.

HYPOTHESIS 2: Usage of Russia's domestic social networking platforms will have no effect on awareness of electoral fraud.

Our third hypothesis also derives from our argument about the conditions under which social media platforms will be primed with information about electoral fraud. As we argue, when press freedom is high, there is more second-hand information available for elite activists to use in their social media posts. This makes it more likely that elite activists will have the 'tools' to be able to politicize social media outlets. Thus, our third hypothesis is the following.

HYPOTHESIS 3: The effect of online social media usage on awareness of electoral fraud will be higher in those Russian regions with higher levels of press freedom.

\section{DATA AND METHODS}

Our main data source is a representative survey of 1,600 Russians conducted by the Levada Center during December 16-20, 2011. ${ }^{47}$ Our dependent variable comes from responses to a question about awareness of electoral fraud, phrased in the following way: 'Do you think there were violations in the counting of ballots during these elections, and,

45 See http://www.gazeta.ru/news/lastnews/2011/12/09/n_2129114.shtml

46 See http://interfax.ru/politics/txt.asp?id=220139, 'V Facebook i Twitter pobedila demokratiya', Interfax, December 5, 2011.

47 The Levada Center conducts its monthly Omnibus (or Courier) survey from 1,600 residents in 130 primary sampling units across 45 regions. Interviews were conducted face to face in the home of the respondent and consisted of a variety of questions on contemporary social, economic, and political issues. The margin of error is less than 3.4 percent. For details on the survey design in Russian, see http:// www.levada.ru/omnibusnyi-opros 
if so, how significant were they?' Respondents were offered four options: no violations (16 percent), insignificant violations (39 percent), somewhat significant violations that did not affect the final results ( 25 percent), and significant violations that affected the results (19 percent). From this, we construct an ordinal dependent variable ranging from 1 if a respondent thought there were no violations to 4 if the respondent thought there were significant violations that affected the results. This survey question makes a good dependent variable because it focuses specifically on awareness of falsification that occurred on election day and not on general attitudes toward the regime or the fairness of the elections.

Our main independent variables are constructed from the aforementioned question about respondents' usage of various online social media platforms (see Table 1). Twitter and/or Facebook User is an ordinal variable equal to 2 if the respondent used both Twitter and Facebook, 1 if the respondent used either, and 0 if the respondent used neither. In various models, we also include a series of dummy variables, each equal to 1 if the respondent reported using, Facebook, Twitter, LiveJournal, VKontakte, Odnoklassniki, MoiKrug, or MoiMir.

In Table 2, we show some simple descriptive statistics on the usage of Facebook and Twitter. Column 1 presents the sample means for respondents who do not use Facebook, while Column 2 shows the sample mean for Facebook users. Columns 3 and 4 show the means for Twitter users and non-users. The differences between each of two groups are also shown, with standard t-tests run to measure whether the means are statistically different from one another. As we can see, Facebook and Twitter users do differ from non-users on a number of demographic characteristics (recall that the non-user category also includes respondents who do not access the internet). We see that both Facebook and Twitter users are more likely to be younger, living in larger cities and towns (including Moscow and St Petersburg), and single. They are also more likely to be members of other online social networks, while Twitter users also are slightly better educated. ${ }^{48}$ These differences in basic demographics motivate our use of multivariate regression to control for the potentially confounding effect of these factors on perceptions of fraud.

Importantly though, Facebook and Twitter users do not appear to differ from non-users in their political dispositions and behavior. When it comes to voting rates, partisanship, approval ratings of Vladimir Putin, or level of political activism and knowledge, Facebook users are statistically indistinguishable from their non-user counterparts. Though Twitter users do appear to have a lower opinion of Vladimir Putin, they are also less likely to have participated in a political action. Facebook and Twitter users were also not more likely to be engaged in political discussions about the elections. Appendix Table 1 shows the exact wordings of the survey questions used in the models and shows how each variable is coded.

Thus, we control for a series of individual level factors that could both determine perceptions of electoral fraud and be correlated with social media usage patterns. First, we include several variables that control for the political disposition and engagement of respondents: (1) whether the respondent supported Vladimir Putin (Putin Approval), (2) whether the respondent was affiliated with an opposition party (Opposition Supporter), (3) whether the respondent voted (Voted in December Election), and (4) whether the

48 Almost half of Facebook users use VKontakte, but given that VKontakte is so much larger than Facebook, only 10 percent of VKontakte users use Facebook. The same is true of Odnoklassniki, where 9 percent of users use Facebook. Naturally, the same dynamics characterize the overlap between Twitter and these domestic networks. 


\begin{tabular}{|c|c|c|c|c|c|c|}
\hline & $\begin{array}{c}(1) \\
\text { Non-Facebook user } \\
\text { Mean }\end{array}$ & $\begin{array}{c}(2) \\
\text { Facebook user } \\
\text { Mean }\end{array}$ & Diff. & $\begin{array}{c}\text { (3) } \\
\text { Non-Twitter user } \\
\text { Mean }\end{array}$ & $\begin{array}{l}\text { (4) } \\
\text { Twitter user } \\
\text { Mean }\end{array}$ & Diff. \\
\hline Male & 0.44 & 0.60 & $-0.16 * *$ & 0.45 & 0.62 & -0.17 \\
\hline Age & 44.46 & 37.61 & $6.85 * * *$ & 44.32 & 30.92 & $13.40 * * *$ \\
\hline Household Income (Logged) & 8.43 & 7.96 & 0.46 & 8.41 & 8.15 & 0.25 \\
\hline Size of Settlement & 3.00 & 3.75 & $-0.75 * *$ & 3.01 & 4.62 & $-1.61 * * *$ \\
\hline Unmarried & 0.35 & 0.53 & $-0.18 * *$ & 0.36 & 0.58 & $-0.22 *$ \\
\hline Level of Education & 5.28 & 5.46 & -0.18 & 5.28 & 6.19 & $-0.92 *$ \\
\hline Employed & 0.60 & 0.55 & 0.05 & 0.60 & 0.62 & -0.02 \\
\hline Consumer of Foreign Media & 0.16 & 0.20 & -0.05 & 0.16 & 0.27 & -0.11 \\
\hline Voted in December Election & 0.30 & 0.34 & -0.04 & 0.31 & 0.15 & 0.15 \\
\hline Putin Approval & 0.63 & 0.60 & 0.03 & 0.63 & 0.42 & $0.21 *$ \\
\hline Non-partisan & 0.59 & 0.60 & -0.02 & 0.59 & 0.50 & 0.09 \\
\hline Opposition Supporter & 0.21 & 0.27 & -0.05 & 0.21 & 0.35 & -0.13 \\
\hline Participated in Political Action & 4.86 & 4.77 & 0.09 & 4.86 & 4.38 & $0.48 * * *$ \\
\hline Lives in Moscow or St. Petersburg & 0.10 & 0.20 & $-0.11 * *$ & 0.10 & 0.35 & $-0.25 * * *$ \\
\hline Aware of Protests & 0.85 & 0.92 & -0.07 & 0.85 & 0.96 & -0.11 \\
\hline Discussed Elections with Family/Friends & 1.77 & 1.65 & 0.12 & 1.77 & 1.48 & 0.29 \\
\hline VKontakte user & 0.22 & 0.48 & $-0.26^{* * *}$ & 0.22 & 0.85 & $-0.62 * * *$ \\
\hline Odnoklassniki user & 0.24 & 0.46 & $-0.22 * * *$ & 0.25 & 0.54 & $-0.29 * * *$ \\
\hline
\end{tabular}

Notes: Table shows results from paired $t$-tests between the sample means.

$* * * p<0.01, * * p<0.05, * p<0.1$. 
respondent participated in mass political action in the month before the election (Participated in Political Action). ${ }^{49}$ Second, we control for the respondent's exposure to other media with a dummy variable equal to one if the respondent reported using the Internet and a dummy variable equal to 1 if the respondent reported consuming foreign media at all. The latter taps the respondent's exposure to Western media reports on the elections, which generally emphasized fraud. Moreover, including foreign media consumption is an indirect way of measuring an individual's ties to the West, such as language skills (we presume foreign media is in the English language). Finally, we control for a series of demographic characteristics that might determine perceptions of electoral fraud: These include a dummy variable for whether the respondent Lives in Moscow or St Petersburg, the Size of Settlement where the respondent lives, Household Income (Logged), Age, Level of Education, as well as whether the respondent is Employed, Male, and Unmarried. ${ }^{50}$

The dependent variable is an ordinal variable, so we use ordinal logit models throughout. Robust standard errors are clustered on the primary sampling unit. Robustness checks showing results with fixed effects at the level of the primary sampling unit are published in the appendix.

\section{RESULTS}

The results of our models related to Hypotheses 1 and 2 are in Table 3. As Model 1 shows, Facebook/Twitter users are significantly more likely to believe that there were significant electoral violations in the 2011 elections. Coefficients show average marginal effects, denoting the increase in the predicted probability that a respondent chose the fourth option - Significant violations that affected the results - associated with a one-unit increase in a given independent variable. ${ }^{51}$ The marginal effect of Twitter and/or Facebook User is 0.04 . In other words, a one unit increase in that Twitter and/or Facebook User (i.e. the difference between a respondent who uses neither Facebook nor Twitter and a respondent who uses one of these or the difference between a user who uses one of the two and a respondent who uses both) increases the probability that a respondent will think that electoral violations were significant and affected the results by 4 percentage points. Thus, a two unit increase increases the probability of a respondent perceiving significant violations by over 8 percentage points.

Table 4 gives a better sense of the scale of these effects and shows the predicted probabilities accompanying this model. According to the model, respondents who use neither Facebook nor Twitter have an 18 percent chance of thinking that electoral violations were significant and consequential, while respondents who use both social networks have a 27 percent chance of thinking that violations were significant and consequential. In other words, using both Facebook and Twitter increases the chances that a respondent will believe that there was serious fraud by over 50 percent (an 8 percentage point increase). This indicates support for Hypothesis 1.

49 Putin Approval is not constructed from the same question as Opposition Supporter (see supplementary appendix on author's website).

${ }^{50}$ For ease of exposition, we do not present the point estimates from this final set of demographic control variables, though all of the models include these eight variables. For the point estimates on these control variables, please consult the supplementary appendix to this article on the author's website.

51 Please see the supplementary appendix on the author's website for more on average marginal effects. 
TA B L 3 Determinants of Electoral Fraud Awareness

\begin{tabular}{|c|c|c|c|c|c|c|c|c|}
\hline & Model 1 & Model 2 & Model 3 & Model 4 & Model 5 & Model 6 & Model 7 & Model 8 \\
\hline Internet user & $\begin{array}{l}0.04 * * \\
(0.02)\end{array}$ & $\begin{array}{l}0.05^{* * * *} \\
(0.02)\end{array}$ & $\begin{array}{l}0.05 * * * \\
(0.02)\end{array}$ & $\begin{array}{l}0.05^{* * * *} \\
(0.02)\end{array}$ & $\begin{array}{l}0.04 * * \\
(0.02)\end{array}$ & $\begin{array}{l}0.04 * * \\
(0.02)\end{array}$ & $\begin{array}{l}0.04 * * \\
(0.02)\end{array}$ & $\begin{array}{l}0.05 * * * \\
(0.02)\end{array}$ \\
\hline Consumer of Foreign Media & $\begin{array}{c}-0.00 \\
(0.03)\end{array}$ & $\begin{array}{c}0.00 \\
(0.03)\end{array}$ & $\begin{array}{c}-0.00 \\
(0.02)\end{array}$ & $\begin{array}{c}-0.00 \\
(0.02)\end{array}$ & $\begin{array}{c}-0.00 \\
(0.02)\end{array}$ & $\begin{array}{c}-0.00 \\
(0.03)\end{array}$ & $\begin{array}{c}-0.00 \\
(0.02)\end{array}$ & $\begin{array}{c}-0.00 \\
(0.02)\end{array}$ \\
\hline Voted in December Election & $\begin{array}{l}0.09 * * * \\
(0.02)\end{array}$ & $\begin{array}{l}0.08^{* * * *} \\
(0.02)\end{array}$ & $\begin{array}{l}0.08^{* * * *} \\
(0.02)\end{array}$ & $\begin{array}{l}0.08 \text { *** } \\
(0.02)\end{array}$ & $\begin{array}{l}0.09 * * * \\
(0.02)\end{array}$ & $\begin{array}{l}0.09 \text { *** } \\
(0.02)\end{array}$ & $\begin{array}{l}0.09 \text { *** } \\
(0.02)\end{array}$ & $\begin{array}{l}0.08 * * * \\
(0.02)\end{array}$ \\
\hline Putin Approval & $\begin{array}{c}-0.16^{* * *} \\
(0.03)\end{array}$ & $\begin{array}{c}-0.16^{* * * *} \\
(0.03)\end{array}$ & $\begin{array}{c}-0.16^{* * * *} \\
(0.03)\end{array}$ & $\begin{array}{c}-0.16^{* * * *} \\
(0.03)\end{array}$ & $\begin{array}{c}-0.16^{* * *} \\
(0.03)\end{array}$ & $\begin{array}{c}-0.16^{* * * *} \\
(0.03)\end{array}$ & $\begin{array}{c}-0.16^{* * * *} \\
(0.03)\end{array}$ & $\begin{array}{c}-0.16^{* * *} \\
(0.03)\end{array}$ \\
\hline Non-partisan & $\begin{array}{l}0.15^{* * *} \\
(0.03)\end{array}$ & $\begin{array}{l}0.15^{* * *} \\
(0.03)\end{array}$ & $\begin{array}{l}0.14^{* * *} \\
(0.03)\end{array}$ & $\begin{array}{l}0.15^{* * *} \\
(0.03)\end{array}$ & $\begin{array}{l}0.15^{* * *} \\
(0.03)\end{array}$ & $\begin{array}{l}0.15^{* * *} \\
(0.03)\end{array}$ & $\begin{array}{l}0.15^{* * *} \\
(0.03)\end{array}$ & $\begin{array}{l}0.15^{* * *} \\
(0.03)\end{array}$ \\
\hline Opposition Supporter & $\begin{array}{l}0.18^{* * * *} \\
(0.04)\end{array}$ & $\begin{array}{l}0.18^{* * * *} \\
(0.04)\end{array}$ & $\begin{array}{l}0.18^{* * *} \\
(0.04)\end{array}$ & $\begin{array}{l}0.18^{* * * *} \\
(0.04)\end{array}$ & $\begin{array}{l}0.18^{* * * *} \\
(0.04)\end{array}$ & $\begin{array}{l}0.18^{* * * *} \\
(0.04)\end{array}$ & $\begin{array}{l}0.18^{* * * *} \\
(0.04)\end{array}$ & $\begin{array}{l}0.18^{* * * *} \\
(0.04)\end{array}$ \\
\hline Participated in Political Action & $\begin{array}{c}-0.00 \\
(0.02)\end{array}$ & $\begin{array}{c}-0.00 \\
(0.02)\end{array}$ & $\begin{array}{c}-0.01 \\
(0.02)\end{array}$ & $\begin{array}{c}-0.00 \\
(0.02)\end{array}$ & $\begin{array}{c}-0.00 \\
(0.02)\end{array}$ & $\begin{array}{c}-0.00 \\
(0.02)\end{array}$ & $\begin{array}{c}-0.00 \\
(0.02)\end{array}$ & $\begin{array}{c}-0.00 \\
(0.02)\end{array}$ \\
\hline Lives in Moscow $/ \mathrm{SPb}$ & $\begin{array}{l}0.09 * * * \\
(0.02)\end{array}$ & $\begin{array}{l}0.09 * * * \\
(0.02)\end{array}$ & $\begin{array}{l}0.09 * * * \\
(0.02)\end{array}$ & $\begin{array}{l}0.09 * * * \\
(0.02)\end{array}$ & $\begin{array}{l}0.09 * * * \\
(0.02)\end{array}$ & $\begin{array}{l}0.09 * * * \\
(0.02)\end{array}$ & $\begin{array}{l}0.09 * * * \\
(0.02)\end{array}$ & $\begin{array}{l}0.09 \text { *** } \\
(0.02)\end{array}$ \\
\hline Twitter and/or Facebook user & $\begin{array}{l}0.04 * * * \\
(0.02)\end{array}$ & & & & & & & \\
\hline VKontakte user & & $\begin{array}{c}-0.03 \\
(0.02)\end{array}$ & & & & & & \\
\hline MoiMir user & & & $\begin{array}{c}-0.04 \\
(0.04)\end{array}$ & & & & & \\
\hline Odnoklassniki user & & & & $\begin{array}{c}-0.01 \\
(0.02)\end{array}$ & & & & \\
\hline LiveJournal user & & & & & $\begin{array}{c}0.04 \\
(0.04)\end{array}$ & & & \\
\hline Facebook user & & & & & & $\begin{array}{l}0.05^{* *} \\
(0.02)\end{array}$ & & \\
\hline Twitter user & & & & & & & $\begin{array}{c}0.06^{*} \\
(0.03)\end{array}$ & \\
\hline User of any social network & & & & & & & & $\begin{array}{c}-0.02 \\
(0.02)\end{array}$ \\
\hline Observations & 1,213 & 1,213 & 1,213 & 1,213 & 1,213 & 1,213 & 1,213 & 1,213 \\
\hline
\end{tabular}


TABLE $4 \quad$ Predicted Probability of Electoral Fraud Awareness

\begin{tabular}{lcccc}
\hline \hline & \multicolumn{1}{c}{$\begin{array}{c}\text { No } \\
\text { violations }\end{array}$} & $\begin{array}{c}\text { Insignificant } \\
\text { violations }\end{array}$ & $\begin{array}{c}\text { Violations, but did } \\
\text { not affect results }\end{array}$ & $\begin{array}{c}\text { Significant violations } \\
\text { that affected results }\end{array}$ \\
\hline $\begin{array}{l}\text { Twitter and/or Facebook User (Model 1) } \\
\text { Does not use } \\
\quad \text { Facebook or }\end{array}$ & $0.16[0.13-0.19]$ & $0.39[0.34-0.44]$ & $0.26[0.24-0.28]$ & $0.18[0.148-0.215]$ \\
$\begin{array}{l}\text { Twitter } \\
\text { Uses Facebook } \\
\text { or Twitter }\end{array}$ & $0.13[0.32-0.41]$ & $0.37[0.32-0.41]$ & $0.28[0.26-0.31]$ & $0.22[0.17-0.26]$ \\
$\begin{array}{l}\text { Uses Facebook } \\
\text { and Twitter }\end{array}$ & $0.10[0.05-0.15]$ & $0.33[0.27-0.39]$ & $0.29[0.26-0.33]$ & $0.27[0.19-0.36]$ \\
$\begin{array}{l}\text { Facebook User (Model 7) } \\
\text { Does not use } \\
\text { Facebook }\end{array}$ & $0.16[0.13-0.19]$ & $0.39[0.34-0.44]$ & $0.26[0.24-0.28]$ & $0.18[0.15-0.22]$ \\
\begin{tabular}{l} 
Uses Facebook \\
\hline \hline
\end{tabular} & $0.12[0.07-0.17]$ & $0.36[0.31-0.41]$ & $0.28[0.26-0.31]$ & $0.23[0.17-0.30]$ \\
\hline
\end{tabular}

Note: Square brackets contain dispersion measures of each value.

Just as importantly, the stair step models 2-8 show that no other networks aside from Facebook and Twitter have any statistically or substantively significant effect on awareness of electoral fraud. ${ }^{52}$ This indicates support for Hypothesis 2.

By contrast, as Models 6 and 7 show, users of Facebook and Twitter were significantly more likely to think that there were significant and consequential electoral violations. The effect of Twitter is largest, but given the low numbers of respondents who use Twitter, the standard error is also somewhat large. As Tables 3 and 4 confirm, a one unit increase in using Facebook increases the probability that a respondent will perceive significant violations by 4 percentage points. Put differently, using Facebook results in a 27 percent increase in the probability that a respondent though there was serious fraud.

Results on other variables are also of note. Internet users were more likely to think that fraud was serious, as were those who voted in the December election, and those who did not approve of the job that Vladimir Putin was doing as prime minister. Even when controlling for these factors, both opposition supporters and non-partisan respondents were much more likely than United Russia supporters to think that there was fraud. Denizens of Russia's metropoles, Moscow and St Petersburg, were more likely to think there was fraud. Aside from income, which actually appears to decrease perceptions of fraud, other demographic controls exerted no effect on the probability of perceiving electoral fraud. ${ }^{53}$

Hypothesis 3 stated that the effect of online social media usage would be higher in regions with higher levels of press freedom, because, in these regions, there are some outside sources of information that elite opinion leaders can use to prime social networks with information about fraud. Figure 2 presents a graphic representation of the average

${ }^{52}$ In model not shown, we also examine the effect of MoiKrug and find that it has no effect.

${ }^{53}$ See the supplementary appendix on the author's website for results on these demographic controls. In this supplementary appendix, we carry out several other robustness checks including models using alternative dependent variables, models with fixed effects, models with alternative ways of coding our main independent variables, and models that drop Moscow and St Petersburg. 


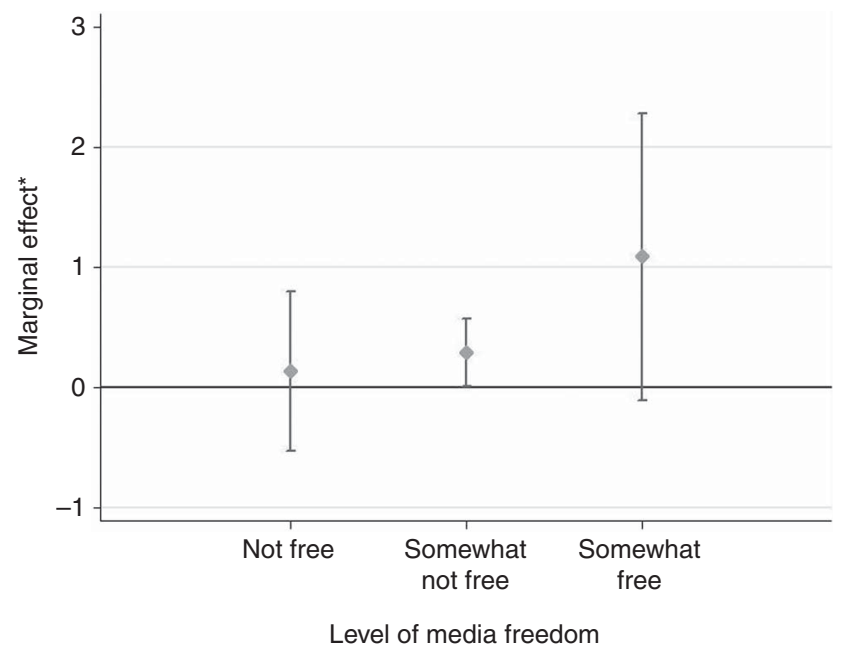

*95\% Confidence intervals shown

Fig. 2. Facebook/Twitter effect conditional on regional media freedom

marginal effects from models that bear out this hypothesis. ${ }^{54}$ On the left side of the figure, we see the marginal effect and 95 percent confidence interval from a regression that restricts the sample to regions with low levels of Press Freedom. In the middle, we see the marginal effect of Twitter/Facebook usages in regions with middle levels of Press Freedom, and on the right we see the marginal effect in regions with relatively high levels of Press Freedom. The effect of Twitter/Facebook usage is statistically insignificant in regions with low press freedom, while in regions with middle levels of Press Freedom, the effect of Twitter and/or Facebook User is positive, significant, and substantively similar to that found in the pooled sample. Finally, in regions with relatively high levels of Press Freedom, the effect of Facebook/ Twitter usage is more than three times as large as in regions with low Press Freedom.

In other words, using Facebook/Twitter increases a respondent's awareness of fraud more in regions with relatively free press. These models similarly control for other regional-level factors that might affect perceptions of electoral fraud as well as could be correlated with press freedom, such as the level of GDP, United Russia's vote share in the 2011 December parliamentary elections, and the share of the population that resides in urban areas. The findings are robust to the inclusion of these controls. Our results thus indicate support for our hypothesis that the effect of online social media usage on awareness of electoral fraud is conditioned by the openness of the broader informational environment inhabited by elite users who prime the social networks with information on fraud.

\section{ENDOGENEITY AND ROBUSTNESS TESTS}

No observational research design can fully eliminate endogeneity concerns. Ours is no exception. In our case, the concern is that people with preformed opinions about electoral

\footnotetext{
54 See Appendix Table 4 to this article for the full models that were used to produce this figure. The independent variables used are the same as in Model 1 of Table 2. We present three split-sample models here to ease exposition. All results are the same using interaction terms or multi-level models.
} 
violations select into usage of Facebook and Twitter and eschew usage of native social media platforms. It could then be possible that Facebook and Twitter have no independent effect on awareness of electoral fraud; users of these services already have opinions about the prevalence of fraud. Theoretically, we believe there are good reasons to think that the direction of causality does run from Facebook/Twitter usage to awareness of fraud. Even if Russians do select into Facebook/Twitter with preconceived notions about electoral fraud and subsequently spread information about fraud through those channels, it stands to reason that a person with no preconceived notions about electoral fraud will have a higher chance of becoming exposed to information about electoral fraud if they are a Facebook user than if they are a VKontakte user. After all, we know from the qualitative accounts cited above that information about fraud was widely disseminated on Facebook/Twitter, but not on VKontakte.

Empirically, we do several things to probe the nature of causality in this relationship. First, treating this issue as an omitted variable problem, we have controlled for those factors that might determine people's pre-conceived notions about electoral fraud, including their views of the current regime, level of education, access to alternative sources of information, and levels of political engagement. Even while holding these factors constant, we find that usage of Facebook and Twitter has a significant positive effect on awareness of fraud.

In order to investigate the possibility of self-selection in greater detail, we split our sample into two groups, those who indicated that they supported Vladimir Putin $(1,004$ respondents) and those that did not (596 respondents). Those who oppose Putin are more likely to have preconceived views about the incidence of fraud (indeed 68 percent thought that there were significant or somewhat significant violations (categories 3 and 4 on Electoral Violations)), so there should be less room for Facebook/Twitter to influence opinions about fraud among this group. ${ }^{55}$ Many of these individuals have already been exposed to information about fraud, and these are the type of individuals who should self-select into Facebook/Twitter with pre-conceived notions of fraud. By contrast, Putin supporters are less likely to have pre-conceived notions about fraud. If Facebook/Twitter has an independent effect on awareness of fraud and is not just a proxy for pre-conceived notions of fraud, then we would expect to see that Facebook/Twitter usage has a stronger effect on awareness of fraud among Putin supporters. In Model 1, Table 5, we run our base model using only the sample of Putin supporters and see that Twitter and/or Facebook User has a positive and statistically significant effect. ${ }^{56}$ In Model 2, Table 5, we run the base model on the sample of Putin opponents and see that the marginal effect on Twitter and/or Facebook User is 0.03 and not statistically significant. ${ }^{57}$ This indicates that the primary effect of Facebook/Twitter usage is to inform erstwhile regime supporters about fraud. It also increases awareness of fraud among regime opponents, but the effect is not statistically significant. This could be due to the smaller sample size or due to the fact that the effect of Facebook/Twitter is difficult to estimate with certainty in a sample that already exhibits high levels of fraud awareness for other reasons.

\footnotetext{
55 Twenty-seven percent of Putin supporters thought there was some significant fraud (categories 3 or 4$)$.

56 All model results in this table are substantively and statistically similar if we use the Facebook dummy variable in place of the Twitter and/or Facebook User variable.

57 These split sample results are similar if we divide the sample using the Opposition Supporters variable. The results are also similar if we use Facebook User as the independent variable.
} 
TABLE 5 Determinants of Electoral Fraud Awareness: Robustness Checks

\begin{tabular}{lcccc}
\hline \hline & Model 1 & Model 2 & Model 3 & Model 4 \\
\hline Internet user & $0.02^{*}$ & $0.08^{*}$ & & $0.06^{* * *}$ \\
& $(0.01)$ & $(0.04)$ & & $(0.02)$ \\
Consumer of Foreign Media & -0.03 & $0.07^{* *}$ & -0.03 & -0.00 \\
& $(0.02)$ & $(0.03)$ & $(0.03)$ & $(0.03)$ \\
Voted in December Election & $0.07^{* * *}$ & 0.04 & 0.05 & $0.08^{* * *}$ \\
& $(0.02)$ & $(0.05)$ & $(0.04)$ & $(0.02)$ \\
Putin Approval & & & $-0.18^{* * *}$ & $-0.16^{* * *}$ \\
& & & $(0.04)$ & $(0.03)$ \\
Non Partisan & $0.08^{* * *}$ & $0.37^{* * *}$ & $0.19^{* * *}$ & $0.14^{* * *}$ \\
& $(0.02)$ & $(0.10)$ & $(0.04)$ & $(0.03)$ \\
Opposition Supporter & $0.12^{* * *}$ & $0.33^{* * *}$ & $0.22^{* * *}$ & $0.18^{* * *}$ \\
& $(0.03)$ & $(0.11)$ & $(0.05)$ & $(0.04)$ \\
Participated in Political Action & -0.02 & 0.01 & -0.02 & -0.00 \\
& $(0.01)$ & $(0.03)$ & $(0.03)$ & $(0.02)$ \\
Lives in Moscow/SPb & $0.04^{* * *}$ & $0.22^{* * *}$ & $0.10^{* * *}$ & $0.09^{* * *}$ \\
Twitter and/or Facebook user & $(0.01)$ & $(0.07)$ & $(0.03)$ & $(0.02)$ \\
VKontakte user & $0.03^{* *}$ & 0.03 & $0.05^{* *}$ & $0.05^{* * *}$ \\
Odnoklassniki user & $(0.02)$ & $(0.04)$ & $(0.02)$ & $(0.02)$ \\
& & & & -0.02 \\
MokKrug user & & & & $-0.02)$ \\
Moi Mir user & & & & $(0.01)$ \\
LiveJournal user & & & 0.01 \\
Observations & & & & $-0.04)$ \\
& & & & $(0.04)$ \\
\hline \hline
\end{tabular}

Notes: Marginal Effects from Ordinal Logit Models; standard errors, clustered on primary sampling unit in parentheses. Dependent Variable: Awareness of Electoral Fraud. Model 1: Sample Restricted to Putin Supporters. Model 2: Sample Restricted to Putin Non-Supporters. Model 3: Sample Restricted to Users of Social Media. Model 4: All Social Networks Included in Same Model. ${ }^{* * *} p<0.01,{ }^{* *} p<0.05,{ }^{*} p<0.1$.

It is also worth pointing out that the findings in Figure 2 support the perspective that usage of Facebook and Twitter drives awareness of electoral fraud. There is no reason to think that people with preconceived views on fraud would be more likely to select into Facebook and Twitter in regions with high press freedom than in regions with low press freedom. By contrast, if these networks must first be primed with information on fraud in order to affect users' perceptions of fraud, then we would expect to see the results that we find.

Additionally, if those with preconceived views about fraud select into Facebook/ Twitter, then usage of these networks can be taken as proxies for having preconceived ideas about the prevalence of fraud, and Facebook/Twitter usage should then predict other political positions that are associated with having preconceived views about the regime's electoral conduct. For example, those who support liberal opposition activist Alexei Navalny are likely to believe that fraud was extensive given that Navalny's public positions were founded on this premise. Thus, Facebook/Twitter usage should predict support for Navalny. We investigate this premise in Appendix Table 5 in the appendix and find that it does not. Nor does Facebook/Twitter usage predict other liberal positions that are commonly associated with presumptions about widespread fraud. It does not 
predict support for opposition candidate Mikhail Prokhorov, lack of support for Vladimir Putin, vote for non-regime parties, or abstention during the elections. If Facebook/Twitter usage were simply a proxy for those with liberal views (such as the view that electoral fraud was extensive), then Facebook/Twitter usage should also predict liberal positions/actions. It does not. This, combined with the fact that Facebook/Twitter usage is associated with awareness of fraud, indicates that usage of these social networks increased awareness of fraud. In sum, we acknowledge the potential for endogeneity in our empirical analysis, but the evidence at our disposal lends itself toward the interpretation that Facebook/Twitter usage increases awareness of fraud.

Finally, in Models 3 and 4 of Table 5 we examine the effect of Facebook/Twitter usage when we change the reference group. In Model 1 of Table 3, the reference category includes both individuals who do not use social networks and individuals who use one or more social networks but do not use Facebook or Twitter. By contrast, in Model 1 of Table 5, we include only those respondents who use social networks. Thus, the point estimate on Twitter and/or Facebook User compares users of Facebook and Twitter only to other users of social networks. Here we see that the findings are the same: users of Facebook/ Twitter are significantly more likely to believe that there were serious electoral violations.

Next in Model 4 of Table 5, we examine the effect of Facebook/ Twitter usage, conditional on membership in other social networks. After all, Facebook and Twitter usage often overlaps with usage of other social networks. When controlling for the usage of domestic social networks, we find once again that Facebook/Twitter users are more likely to believe there were electoral violations.

\section{CONCLUSION}

There is no scholarly consensus about the effect of new media on politics in authoritarian regimes. This is because most scholars have tended to view new media as a 'black box', failing to distinguish between the different ways that new media is used. Most studies of new media in authoritarian regimes lack attention to the causal mechanisms that link specific types of new media usage to specific political outcomes. In this article, we examined how a specific type of new media - online social networking sites affects political awareness among citizens in authoritarian regimes. Because it lowers the cost of information acquisition, exposes users to unsought political information, and increases the perceived reliability of that information, online social media has the potential to increase political awareness in non-democracies. However, online social media usage only increases political awareness if the specific social network being used has been politicized to contain political information. Not all online social networks are politicized in this way.

Using original survey data from the Russian 2011-12 election cycle, we showed that usage of politicized social networking platforms increased awareness of electoral fraud in the 2011 parliamentary elections. We find that usage of Facebook and Twitter, which were primed by opposition elites with information about electoral fraud, significantly increased the probability that respondents perceived significant electoral violations. By contrast, usage of Russia's more popular native social networking platforms, VKontakte, Odnoklassniki, MoiMir, and Moi Krug, had no effect on awareness of electoral fraud. These findings are robust to controlling for a range of factors that might also predict awareness of electoral fraud and be correlated with choice of social network. We also find 
that usage of Facebook/Twitter has a larger effect on awareness of electoral fraud in regions with relatively high levels of press freedom. In order to have an effect on awareness of electoral fraud, these social networks must first be primed with information on such fraud. In regions with relatively high levels of press freedom, there is more secondary information about electoral fraud that elites can use to prime those networks. Finally, we find that these networks may do more to educate regime supporters about the presence of fraud than they do to inform opposition supporters, who may already have opinions about fraud.

Our findings demonstrate both the promise and limitation of online social media as a driver of political change in non-democracies. On the one hand, Facebook and Twitter do seem to increase political awareness in authoritarian regimes. In turn, increased awareness of government malfeasance turns more citizens against the regime and makes anti-regime mobilization more likely. In this way, dictators have reason to fear the rapid expansion of online social networking. At the same time, it is worth keeping in mind that even though usage of Facebook and Twitter is expanding rapidly around the globe, the share of voters in most electoral authoritarian regimes that actually use these networks is still quite low only about 7 percent of Russian adults, for example. Thus, while the global spread of Facebook and Twitter has undermined and will continue to undermine the ability of authoritarian regimes to control information flows, the past and present effects of social networking on democratization should not be overstated.

What is more, in regimes such as Russia, China, Vietnam, and Iran, the user base of native social networking sites still dwarfs the user base of Facebook and Twitter. Authoritarian leaders are better able to control the spread of anti-regime information on these networks. The worldwide homogenization of social networking continues apace, but where native social networking platforms continue to dominate the market, authoritarian leaders will be more successful at blunting the democratizing effects of online social media.

Finally, our work has important implications for the determinants of anti-regime mobilization in authoritarian regimes. As studies of mass mobilization under autocracy demonstrate, opposition mobilization is most likely when citizens are aware that antiregime grievances have become widespread. ${ }^{58}$ This knowledge of mutually shared grievances reduces both the perceived costs of collective action and the likelihood that citizens will 'falsify' their anti-regime preferences. This study highlights a mechanism by which knowledge of mutually shared anti-regime grievances can spread in modern authoritarian regimes.

\section{REFERENCES}

Aday, Sean, Henry Farrell, Marc Lynch, John Sides, John Kelly, and Ethan Zuckerman. 2010. Blogs and Bullets: New Media in Contentious Politics. Peaceworks. United States Institute of Peace.

Alexanyan, Karina, Vladimir Barash, Bruce Etling, Robert Faris, Urs Gasser, John Kelly, John Palfrey, and Hal Roberts. 2012. Exploring Russian Cyberspace: Digitally-Mediated Collective Action and the Networked Public Sphere. Berkman Center Research Publication No. 2012-2, Cambridge, Mass.: Harvard University.

Bailard, Catie Snow. 2012. A Field Experiment on the Internet's Effect in an African Election: Savvier Citizens, Disaffected Voters, or Both? Journal of Communication 62 (2):330-44.

${ }^{58}$ Kuran 1991; Tucker 2007. 
Bakshy, Eytan, Itamar Rosenn, Cameron Marlow, and Lada Adamic. 2012. The Role of Social Networks in Information Diffusion. Arxiv preprint arXiv:1201.4145. Available from http:// arxiv.org/abs/1201.4145, accessed July 17, 2012.

Balmforth, Tom , 'Russian Opposition “Likes” Facebook'. Radio Free Europe/Radio Liberty, May 18, 2012. Available from http://www.rferl.org/content/russian-opposition-likes-facebook/ 24585388.html, accessed July 22, 2012.

Beissinger, Mark. 2007. Structure and Example in Modular Political Phenomena: The Diffusion of the Bulldozer/Rose/Orange/Tulip Revolutions. Perspectives on Politics 5 (2):259-76.

Boulianne, Shelley. 2009. Does Internet Use Affect Engagement? A Meta-Analysis of Research. Political Communication 26 (2):193-211.

Boyd, Danah M, and Nicole Ellison. 2007. Social Network Sites: Definition, History, and Scholarship. Journal of Computer-Mediated Communication 13 (1):210-30.

Campus, Donatella, Gianfranco Pasquino, and Cristian Vaccari. 2008. Social Networks, Political Discussion, and Voting in Italy: A Study of the 2006 Election. Political Communication 25 (4):423-44.

Cottle, Simon. 2011. Media and the Arab Uprisings of 2011: Research Notes. Journalism $12(5): 647-59$.

De Vreese, Claes, and Hajo Boomgaarden. 2006. News, Political Knowledge and Participation: The Differential Effects of News Media Exposure on Political Knowledge and Participation. Acta Politica 41 (4):317-41.

Deibert, Ronald, and Rafal Rohozinski. 2010. Beyond Denial: Introducing Next Generation Access Controls. in Deibert, Ronald, et al. eds., Access Controlled: The Shaping of Power, Rights, and Rule in Cyberspace. Cambridge, Mass.: MIT Press.

Enikolopov, Ruben, Vasily Korovkin, Maria Petrova, Konstantin Sonin, and Alexei Zakharov. 2013. Electoral Fraud in Russian Parliamentary Elections in December 2011: Evidence from a Field Experiment. Proceedings of the National Academy of Sciences 110 (2):448-52.

Eveland, William P., and Dietram A. Scheufele. 2000. Connecting News Media Use with Gaps in Knowledge and Participation. Political Communication 17 (3):215-37.

Farrell, Henry. 2012. The Consequences of the Internet for Politics. Annual Review of Political Science 15 (1):35-52.

Gajora, Liviu. 2011. Effects of Internet Use on Actual and Self-perceived Political Knowledge, Issue Certainty and Political Participation. Master's dissertation. Available from http:// wakespace.lib.wfu.edu/jspui/bitstream/10339/33436/1/Gajora_wfu_0248M_10096.pdf, accessed July 22, 2012.

Gil De Zuniga, Homero, Eulalia Puig-I-Abril, and Hernando Rojas. 2009. Weblogs, Traditional Sources Online and Political Participation: An Assessment of How the Internet Is Changing the Political Environment. New Media \& Society 11 (4):553-74.

Greene, Samuel. 2012. Twitter and the Russian Street: Memes, Networks \& Mobilization. CNMS Working Paper 2012/1. Center for the Study of New Media and Society, Moscow.

Groshek, Jacob, and Daniela Dimitrova. 2011. A Cross-Section of Voter Learning, Campaign Interest and Intention to Vote in the 2008 American Election: Did Web 2.0 Matter? Communication Studies Journal 9:355-75.

Howard, Phillip, and Muzammil Hussain. 2011. The Role of Digital Media. Journal of Democracy $22(3): 35-48$.

Huckfeldt, Robert, and John Sprague. 1995. Citizens, Politics, and Social Communication: Information and Influence in an Election Campaign. Cambridge: Cambridge University Press.

Kalathil, Shanthi, and Taylor Boas. 2003. Open Networks, Closed Regimes: The Impact of the Internet on Authoritarian Rule. Washington, D.C.: Carnegie Endowment for International Peace.

Kaufhold, Kelly, Sebastian Valenzuela, and Homero Gil de Zúñiga. 2010. Citizen Journalism and Democracy: How User-Generated News Use Relates to Political Knowledge and Participation. Journalism \& Mass Communication Quarterly 87:515-29. 
Kuran, Timur. 1991. Now Out of Never: The Element of Surprise in the East European Revolution of 1989. World Politics 44 (1):7-48.

Lessig, Lawrence. 1999. Code and Other Laws of Cyberspace. New York, N.Y.: Basic Books.

Lynch, Marc. 2011. After Egypt: The Limits and Promise of Online Challenges to the Authoritarian Arab State. Perspectives on Politics 9 (2):301-10.

Miller, Joanne, and Jon Krosnick. 2000. News Media Impact on the Ingredients of Presidential Evaluations: Politically Knowledgeable Citizens Are Guided by a Trusted Source. American Journal of Political Science 44 (2):301-15.

Miner, Luke 2011. The Unintended Consequences of Internet Diffusion: Evidence from Malaysia. Unpublished Job Market Paper, 1-71.

Morozov, Evgeny. 2011. The Net Delusion: The Dark Side of Internet Freedom. New York: Public Affairs.

Mullainathan, Sendhil, and Andrei Shleifer. 2005. The Market for News. American Economic Review 95 (4):1031-53.

Pasek, Josh, Eian More, and Daniel Romer. 2009. Realizing the Social Internet? Online Social Networking Meets Offline Civic Engagement. Journal of Information Technology \& Politics 6:3-4.

Prior, Markus. 2005. News v. Entertainment: How Increasing Media Choice Widens Gaps in Political Knowledge and Turnout. American Journal of Political Science 49 (3):594-609.

Reuter, Ora John. 2011. United Russia and the 2011 Elections. Russian Analytical Digest 102 September, 26.

Shirky, Clay. 2011. The Political Power of Social Media. Foreign Affairs January/February: 1-9.

Siegel, David. 2008. Social Networks and Collective Action. American Journal of Political Science 53 (1):122-38.

Sunstein, Cass. 2002. Republic.com. Princeton, N.J.: Princeton University Press.

Swigger, Nathaniel. 2012. The Online Citizen: Is Social Media Changing Citizens' Beliefs about Democratic Values? Political Behavior, forthcoming.

Thompson, Mark, and Phillipp Kuntz. 2004. Stolen Elections: The Case of the Serbian October. Journal of Democracy 15:159-72.

Tonkin, Emma, Heather Pfeiffer, and Greg Tourte. 2012. Twitter, Information Sharing and the London Riots. Bulletin of the American Society for Information Science and Technology 38 (2):49-57.

Tucker, Joshua. 2007. Enough! Electoral Fraud, Collective Action Problems, and Post-communist Colored Revolutions. Perspectives on Politics 5 (3):535-51.

Tufekci, Zeynep, and Christopher Wilson. 2012. Social Media and the Decision to Participate in Political Protest: Observations from Tahrir Square. Journal of Communication 62 (2):363-79.

Yang, Jaewon, and Jure Leskovec. 2010. Modeling Information Diffusion in Implicit Networks. Data Mining (ICDM), 2010 IEEE 10th International Conference), 599-608.

Zaller, John. 1992. The Nature and Origins of Mass Opinion. New York: Cambridge University Press. 